Manuela Ingaldi ${ }^{l}$, Szymon T. Dziuba ${ }^{2}$

\title{
CHARAKTERYSTYKA GOSPODARSTW DOMOWYCH Z EKOLOGICZNEGO PUNKTU WIDZENIA
}

\begin{abstract}
Streszczenie: Coraz więcej można usłyszeń o gospodarstwach ekologicznych oraz o tym jak prowadzić gospodarstwo domowe w sposób ekologiczny. Należy pamiętać, że ekologia w domu nie oznacza, że ludzie nowoczesne rozwiązania, które kosztują wiele, a które mają zredukować wpływ na środowisko naturalne. Każdy może podjąć działania, które nie wymagają dużych wydatków, a które będą mieć pozytywny wpływ na środowisko naturalne. Celem artykułu jest zbadanie doświadczeń i przyzwyczajeń mieszkańców Polski pod kątem prowadzenia gospodarstwa domowego w sposób ekologiczny. Badanie miało formę ankiety internetowej. Badanie prowadzone było w okresie czerwiec-grudzień 2017. Dzięki ankiecie można było przyjrzeć się przyzwyczajeniom polaków w aspekcie ekologicznego prowadzenia domu.
\end{abstract}

Słowa kluczowe: dom ekologiczny, środowisko naturalne, oszczędności, budżet domowy

\section{Wstęp}

W Polsce według statystyk istnieje 12 milionów gospodarstw domowych, w tym domów jednorodzinnych, wielorodzinnych i mieszkań. Każde gospodarstwo domowe ma wpływ na stan środowiska naturalnego (pozytywny lub negatywny). Aby wpływ ten był pozytywny, nie musimy wprowadzać działań na dużą skalę, które będą wiązały się z dużymi inwestycjami finansowymi i obciążeniem budżetu domowego, jak np. montaż paneli słonecznych, budowa wiatraka, budowa domu ekologicznego, pasywnego. Wystarczą proste działania, takie jak przemyślane zakupy, segregacja śmieci, oszczędne zużycie wody czy energii elektrycznej i cieplnej, które nic nie kosztują, wymagają jedynie zmiany naszego podejścia i przyzwyczajeń, ale mogą mieć wpływ na stan środowiska naturalnego [1,2].

Troska o zasoby naturalne, energetyczne i warunki zdrowotne umożliwia nam harmonijne wspólistnienie $\mathrm{z}$ przyrodą. Jest częścią koncepcji zrównoważonego rozwoju, którego możemy być częścią. Jednak najważniejsze jest, żeby zrozumieć taką potrzebę, a następnie wyrobić w sobie przyzwyczajenie do życia w sposób ekologiczny. Najtrudniejszym, ale nie niemożliwym elementem jest zmiana nastawienia i wyrobienie w sobie tych przyzwyczajeń $[3,4]$.

Coraz częściej słyszy się na temat domów ekologicznych oraz prowadzenia gospodarstwa domowego w sposób ekologiczny.

\footnotetext{
${ }^{1}$ dr inż. Manuela Ingaldi, Politechnika Częstochowska, Wydział Zarządzania, manuela@gazeta.pl

${ }^{2}$ dr inż. Szymon T., Dziuba, Uniwersytet Ekonomiczny we Wrocławiu, szymon.dziuba@ue.wroc.pl
} 
Dom ekologiczny jest przyjazny dla środowiska. Takie jest jego zadanie, aby podczas eksploatacji minimalizowany był jego niekorzystny wpływ na otoczenie. $\mathrm{Z}$ punktu widzenia energooszczędności, $\mathrm{z}$ całą pewnością musi to być dom zużywający jak najmniej energii, redukując przy tym ślad węglowy. Ideałem byłby dom pasywny, albo wręcz dom zero-energetyczny, tj. autonomiczny. Dom pasywny wykorzystuje energię z promieniowania słonecznego w sposób pasywny, czyli biernie bez wykorzystania aktywnych rozwiązań instalacyjnych. Natomiast dom autonomiczny to dom, który może funkcjonować niezależnie od zewnętrznej infrastruktury, to jest bez dostarczania z zewnątrz energii elektrycznej, wody oraz bez odbierania ścieków i kanalizacji burzowej.

Niektórzy definiują dom ekologiczny jest to dom, którzy został wybudowany przy wykorzystaniu zachowań właściwych dla zrównoważonego rozwoju, w szczególności przejawiająca się w dbałości o środowisko naturalne oraz oszczędne gospodarowanie surowcami w całym cyklu budowlanym: począwszy od projektu, poprzez prace konstrukcyjne, eksploatację budynku, aż po rozbiórkę $[5,6]$.

Ale ekologia w domu nie oznacza, że człowiek musi inwestować w nowoczesne rozwiązania, które dużo kosztują, a które mają wpływać na zmniejszenie oddziaływania na środowisko naturalne. Każda osoba może wypracować pewne działania wśród domowników, które nie będą wymagały dużych nakładów finansowanych, a które będą $\mathrm{w}$ sposób pozytywny oddziaływać na środowisko naturalne. To życie zgodnie z tym środowiskiem. Do takich działań można zaliczyć wyłączanie świateł czy urządzeń elektrycznych, kiedy ich nie potrzebujemy, branie prysznica zamiast kąpieli, mycie zębów przy zakręconej wodzie, kupowanie urządzeń energooszczędnych, nieprzegrzewanie pomieszczeń, odpowiednie planowanie zakupu żywności, używanie wielorazowych toreb w czasie zakupów, korzystanie z naczyń wielorazowego użytku, materiałowych chusteczek czy ręczników, pieluch dla dzieci, niewyrzucanie niepotrzebnych rzeczy, ale ich sprzedaż, segregację odpadów, przykrywanie garnków w czasie gotowania, korzystanie z transportu publicznego [7].

Należy podkreślić, że wszystkie te działania nie tylko pomogą nam żyć w zgodnie z naturą, ale oszczędne wykorzystanie jego zasobów może obniżyć koszty życia i wpłynąć pozytywnie na nasz budżet domowy. To także wskazówki dla naszych dzieci, jak powinny żyć, aby dostępne obecnie zasoby naturalne wystarczyły także dla przyszłych pokoleń $[8,9]$.

Celem artykułu jest zbadanie doświadczeń i przyzwyczajeń mieszkańców Polski pod kątem prowadzenia gospodarstwa domowego w sposób ekologiczny. Badanie miały formę internetowej ankiety. Badanie prowadzone było w okresie czerwiec-grudzień 2017. Dzięki ankiecie można było przyjrzeć się przyzwyczajeniom polaków w aspekcie ekologicznego prowadzenia domu. 


\section{Metodologia}

Badania dotyczące życia i prowadzenia domu w sposób uwzględniających dbanie o środowisko naturalne przez mieszkańców Jury Krakowsko-Częstochowskiej przeprowadzono za pomocą ankiety internetowej. Ankieta złożona była z dwóch części: części zasadniczej i metryczki.

Główna część ankiety składała się z 27 pytań. W pierwszych dwóch pytaniach zapytano respondentów, czy żyją w sposób ekologiczny i prowadzą swój dom w taki sposób. Następnie zapytano, czy segregują i jeśli tak, to jakie grupy. Mieli także wskazać, w jaki sposób pozbywają się śmieci czy zauważyli, że ich sąsiedzi palą śmieci.

W dalszej kolejności zadano pytania dotyczące typowych zachowań i przyzwyczajeń związanych z prowadzeniem domu. Zapytano, czy respondenci na zakupach korzystają ze swoich toreb i czy korzystają z transportu publicznego. Następnie respondenci mieli powiedzieć, czy w czasie zakupów sprzętu RTV i AGD oraz żarówek zwracają uwagę na to, żeby ten sprzęt był energooszczędny. W dalszej kolejności respondenci mieli powiedzieć, co robią ze zużytym sprzętem elektrycznym oraz czy zużyte baterie i akumulatory oddają do odpowiednich punktów odbioru.

W dalszej kolejności zapytano, czy respondenci wyłączają światło, kiedy wychodzą z pomieszczeń oraz czy odłączają $\mathrm{z}$ prądu nieużywane urządzenia elektryczne, czy też trzymają je w trybie czuwania. Zapytano także, ile urządzeń kuchennych znajduje się w ich domu. Następnie respondenci mieli powiedzieć, czy ich pralka automatyczna jest używana tylko wtedy, kiedy bęben jest pełny oraz jaki jest ich czajnik.

Kolejne pytanie dotyczyło deklaracji co do oszczędnego wykorzystywania wody oraz sposobu zmywania naczyń. Respondenci mieli także powiedzieć, co robią z przeterminowanymi lekarstwami. Następnie mieli powiedzieć, jakiego używają dezodorantu i jakich pojemników na jajka. Potem mieli wskazać, ile wynosi temperatura $\mathrm{w}$ ich sypialni. Kolejne pytania dotyczyły rodzaju papieru toaletowego oraz wykorzystania papierowych ręczników i serwetek. W ostatnim pytaniu zapytano respondentów o opakowania kupowanych przez nich warzyw i owoców.

W metryczce zadano sześć pytań, dzięki którym możliwa była analiza struktury respondentów. Zapytano w niej o płeć, wiek, pracę, wykształcenie, miejsce zamieszkania.

\section{Wyniki badań}

W badaniu wzięło udział 227 osób zamieszkujących tereny Jury KrakowskoCzęstochowskiej. Badanie miało formę ankiety internetowej. Ankieta była 
udostępniana na różnych formach internetowych oraz portalach społecznościowych. Badanie prowadzone było w okresie maj-wrzesień 2017. Ankieta ta jest częścią większego projektu dotyczącego podejście ekologicznego mieszkańców z terenów Jury Krakowsko-Częstochowskiej. W artykule, ze względu na ograniczenia w jego objętości, przedstawione będą tylko wybrane wyniki ankiety.

$\mathrm{Na}$ początku zapytano respondentów, czy prowadzą swoje domy w sposób ekologiczny (Rys. 1). Tylko 9\% powiedziało, że tak, dodatkowo 55,7\% odpowiedziało, że tak, ale e wybranych aspektach. Aż 30,7\% wprost odpowiedziało, że nie. Powody takiej struktury odpowiedzi można będzie zaobserwować analizując pozostałe wyniki badań.

Następnie zapytano, czy respondenci segregują odpady (Rys. 2). 31,8\% odpowiedziało, że tak, a 53,4\% że częściowo. 14,8\% zaprzeczyło. Można więc zauważyć, że pomimo wysokiemu udziałowi procentowi negatywnej odpowiedzi na poprzednie pytanie wiele ludzi segreguje śmieci, czyli w pewien sposób dba o środowisko. Być może respondenci nie traktują tego działania jako część prowadzenia ekodomu, ponieważ segregacja śmieci $\mathrm{w}$ wielu przypadkach została wymuszona przepisami prawnymi i wyższymi opłatami za wywóz śmieci nieposegregowanych.

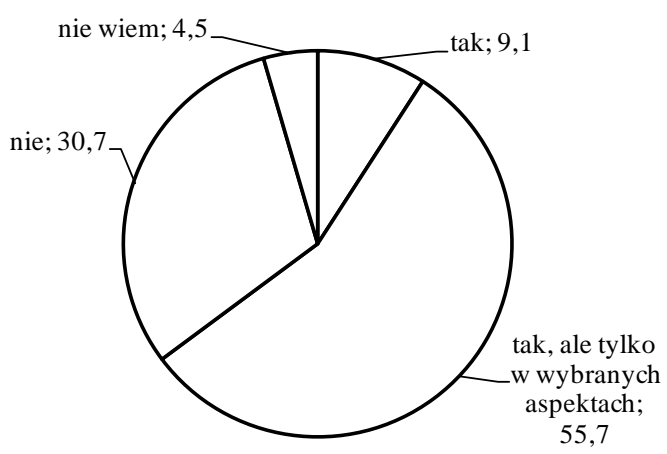

Rys. 1. Czy Pan/Pani stara się prowadzić swój dom w sposób ekologiczny?, \%

Źródto: Opracowanie własne

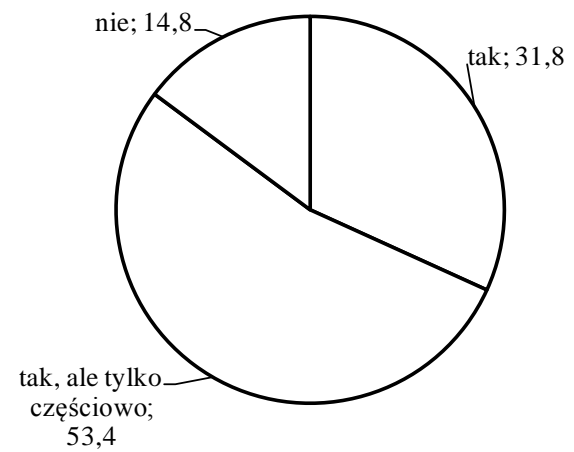

Rys. 2. Czy segreguje Pani /Pan odpady?, $\%$

Źródto: Opracowanie własne

Następnie zapytano respondentów, w jaki sposób pozbywają się śmieci (Rys. 3). Większość respondentów wyrzuca je do osiedlowego lub własnego kontenera $(89,8 \%)$. Jest to najprostszy sposób. Niewielka ilość respondentów wskazała inne odpowiedzi, w przypadku odpowiedzi inne odnotowano wskazanie odpowiedzi wywożenia śmieci do Punktu Selektywnego Zbierania Odpadów Komunalnych. 


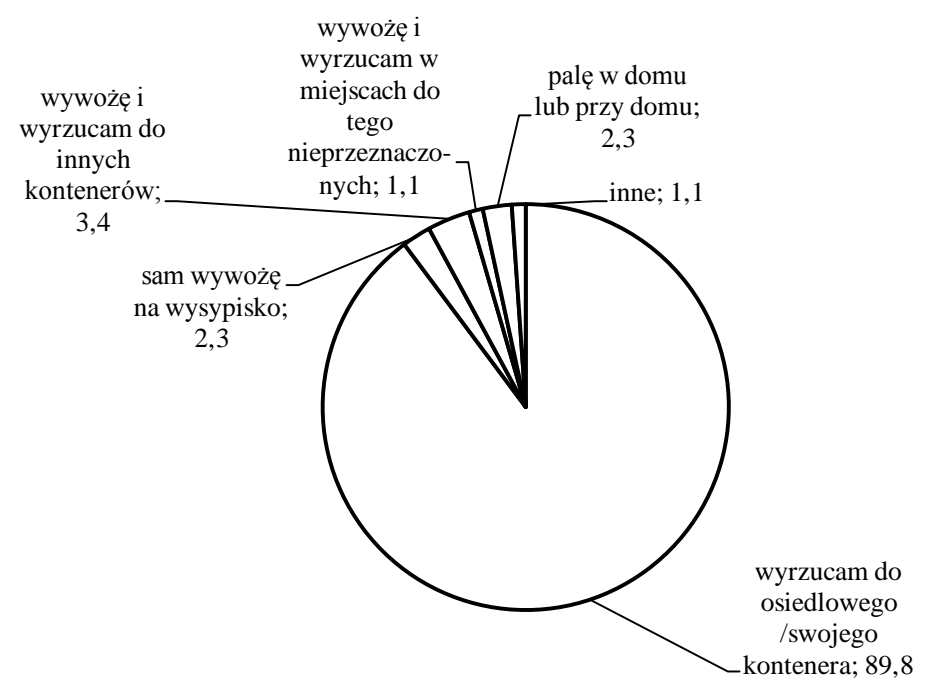

Rys. 3. W jaki sposób pozbywa się Pan/Pani śmieci?, \%

Źródto: Opracowanie wtasne

$62,5 \%$ respondentów powiedziało, że temperatura $\mathrm{w}$ ich sypialni wynosi 18 $21^{\circ} \mathrm{C}$ (Rys. 4). Deklaracja powyżej tej temperatura wyniosła $29,5^{\circ} \mathrm{C}$. Należy pamiętać, że niewielka różnica $\mathrm{w}$ temperaturze w pomieszczeniach, czy w temperaturze wody powoduje duże zwiększenie zużycia paliwa, a tym samym zwiększa się zanieczyszczenie powietrza.

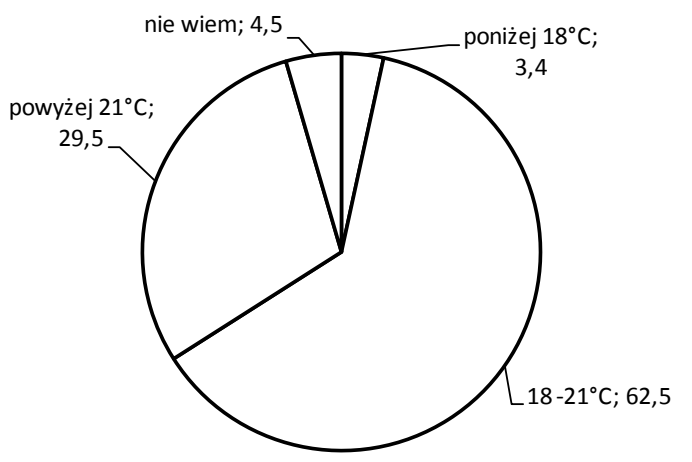

Rys. 4. Ile wynosi temperatura w Pan/Pani sypialni?, \%

Źródto: Opracowanie własne

Następne pytania dotyczyły sprzętu elektrycznego w gospodarstwach domowych. Na początku zapytano, czy respondenci przy zakupie sprzętu zwracają uwagę na to, czy jest on energooszczędny (Rys g. 5). 31,3\% respondentów 
$\overline{\text { odpowiedziało, że zawsze, 23,5\% czasami, a 18,2\% rzadko. W ostatnich latach można }}$ jednak zaobserwować, że klienci coraz częściej zwracają uwagę nie tylko na cenę produktu, ale na koszty jego eksploatacji, co w przypadku mniejszego zużycia energii przekłada się na poprawę stanu środowiska naturalnego.

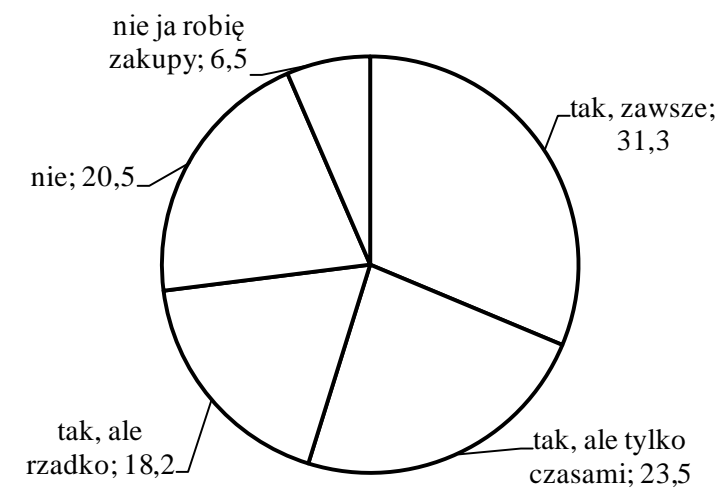

Rys. 5. Czy kupujac sprzęt RTV AGD Pan/Pani zwraca uwage, czy jest to sprzęt energooszczędny?, \%

Źródto: Opracowanie własne

Zapytano także, co się dzieje ze zużytym sprzętem elektrycznym (Rys. 6). Tylko 13,6\% respondentów oddaje go do sklepu, kiedy kupuje nowy, choć sklepy mają obowiązek przyjąć stary sprzęt w takiej sytuacji. 36,4\% respondentów oddaje go do recyklingu. Aż 14,8\% wyrzuca go razem z opadami komunalnymi, chociaż jest to zabronione. W odpowiedzi inne respondenci nie podali swoich odpowiedzi. Odnotowano także 15,9\% odpowiedzi, że respondent nie jest za to odpowiedzialny. Prawdopodobnie są to ludzie młodzi, uczniowie i studenci, którzy nadal mieszkają z rodzicami i to właśnie rodzice odpowiedzialni się za te rzeczy.

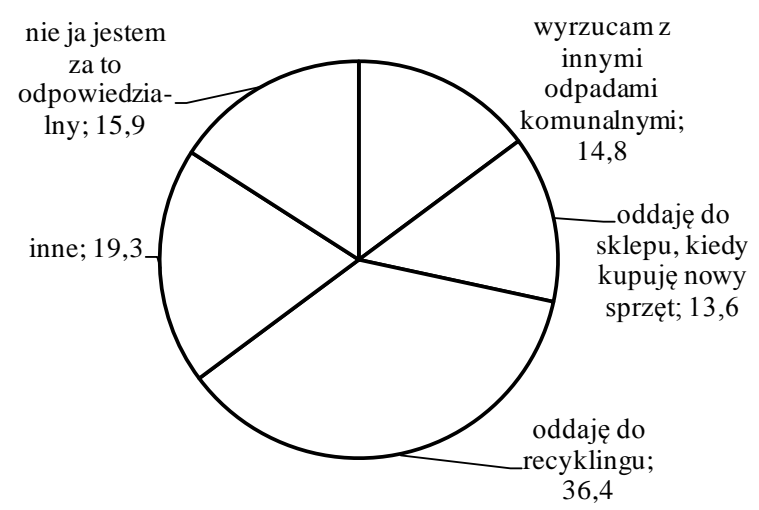

Rys. 6. Co Pan/Pani robi ze zużytym sprzętem elektrycznym?, \%

Źródto: Opracowanie wtasne 
Zapytano, czy zużyte bateria i akumulatory oddawane są do odpowiednich punktów (Rys. 7). 38,7\% respondentów odpowiedziało, że zawsze, 17,4\% czasami. W Polsce w wielu sklepach, również spożywczych, ustawione są pojemniki na zużyte baterie, z których każdy może skorzystać. W przedszkolach i szkołach jest również zorganizowana akcje zbierania zużytych baterii czy sprzętu elektrycznego, a ośrodki, którym udało zebrać najwięcej, dostają za to nagrody i dyplomy. Ponownie odnotowano odpowiedzi, że respondent nie jest za to odpowiedzialny.

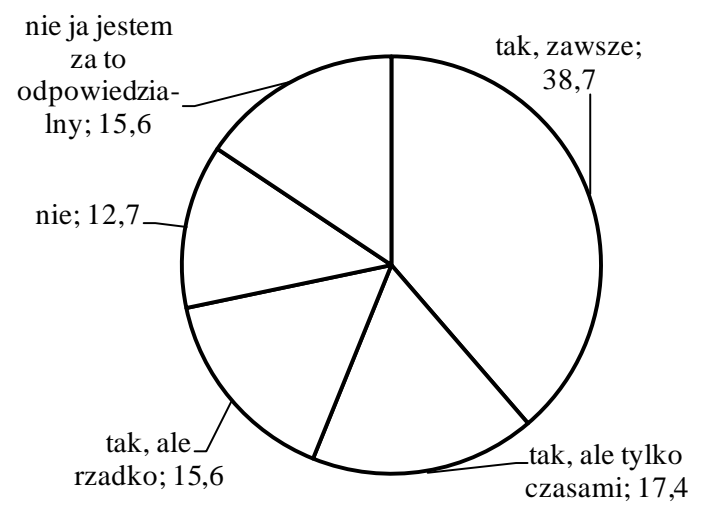

Rys. 7. Czy zużyte baterie i akumulatory oddaje Pan/Pani do specjalnie przeznaczonych do tego punktów?, \%

Źródto: Opracowanie własne

Następnie zapytano, czy respondenci kupują żarówki energooszczędne (Rys. 8). Aż $60,2 \%$ respondentów odpowiedziało, że zawsze, a $17 \%$ czasami. Należy podkreślić, że obecnie w sklepach nie można już kupić żarówek starego typu, które zużywały dużo energii, coraz więcej pojawia się oświetlenia LED. Ceny są coraz niższe, więc klienci decydują się na jego zakup.

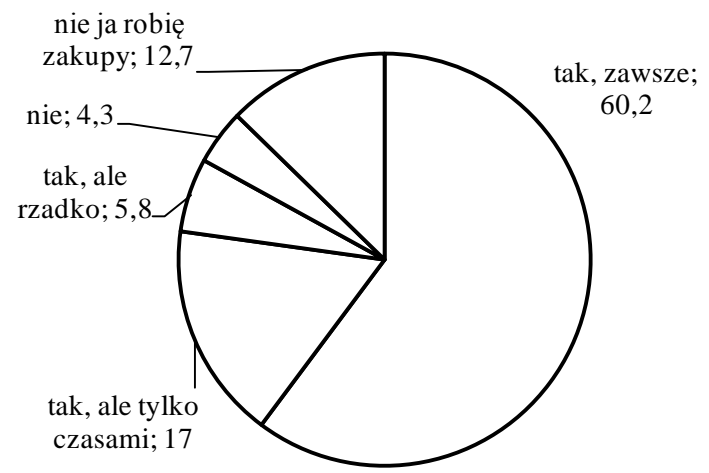

Rys. 8. Czy Pan/Pani kupuje żarówki energooszczędne?, \% 
Zródto: Opracowanie własne

Respondenci mieli także powiedzieć, czy wyłączają światło, kiedy wychodzą z pomieszczeń (Rys. 9) oraz nieużywane urządzenia elektryczne (Rys. 10). 69,3\% osób zadeklarowało, że zawsze wyłącza światło, a 20,5\% czasami. W przypadku nieużywanego sprzętu elektrycznego były to odpowiednio $20,5 \%$ oraz $40,9 \%$. Może to być związane nie tylko z ekologiczną postawą respondentów, ale przede wszystkich $\mathrm{z}$ stale rosnącą ceną energii elektrycznej.

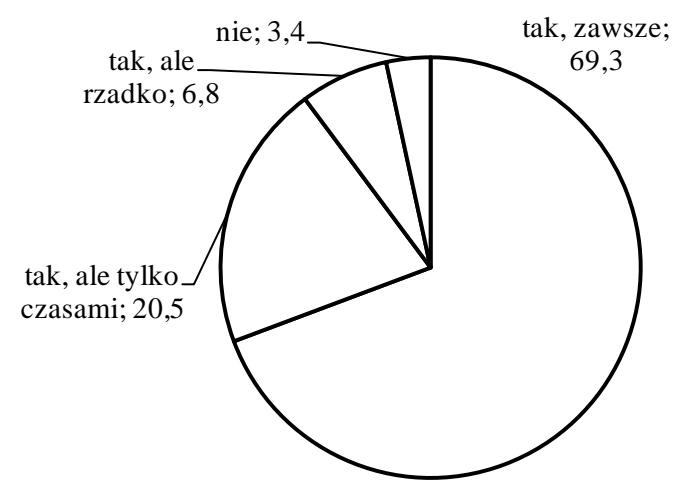

Rys. 9. Czy Pani/Pani wylącza światlo, kiedy wychodzi z pomieszczenia?, \%

Źródto: Opracowanie własne

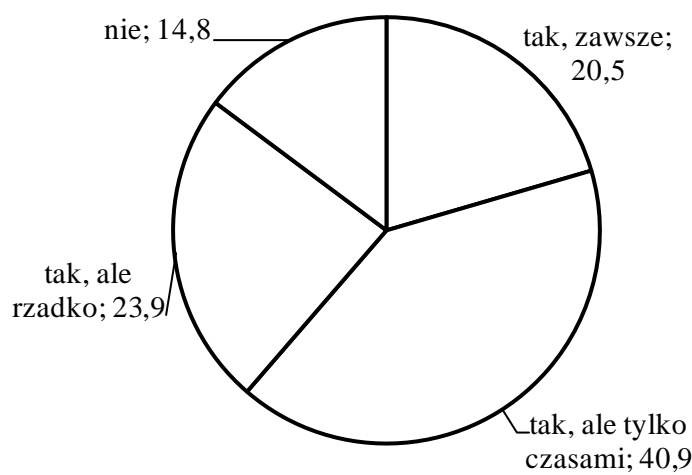

Rys. 10. Czy Pan/Pani wylacza z prądu nieużywane urzadzenia elektryczne?, \%

Źródto: Opracowanie własne

Gospodarstwa domowe są coraz nowocześniejsze, coraz lepiej wyposażone, co przekłada się na liczbę posiadanych urządzeń elektrycznych (Rys. 11). 53,4\% respondentów odpowiedziało, że 53,4\% posiada w kuchni od 5 do 10 różnych urządzeń, a 36,4\% ponad 10 . 


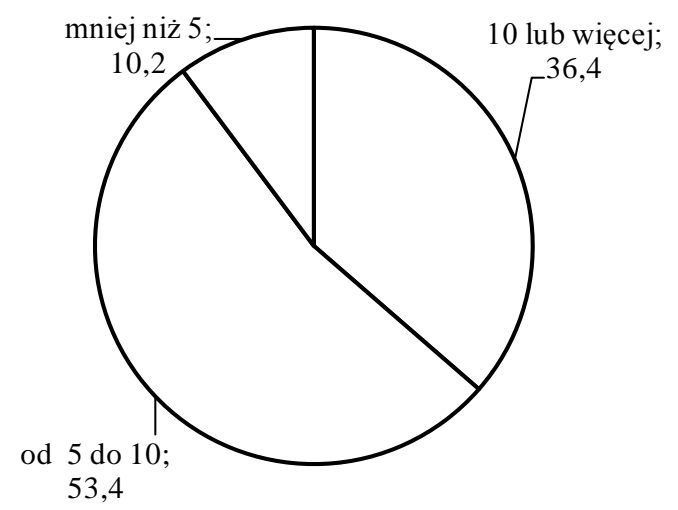

Rys. 11. Ile elektrycznych urzadzeń kuchennych znajduje się w Pana/Pani domu?, \% Źródto: Opracowanie własne

Zapytano także, czy pralka używana jest tylko wtedy, gdy jest napełniona (Rys. 12). Tylko 9,3\% odpowiedziało twierdząco. Aż 36,8\% odpowiedziało przecząco, co oznacza, że te osoby nie są zainteresowane oszczędnościami związanymi ze zużyciem wody czy energii.

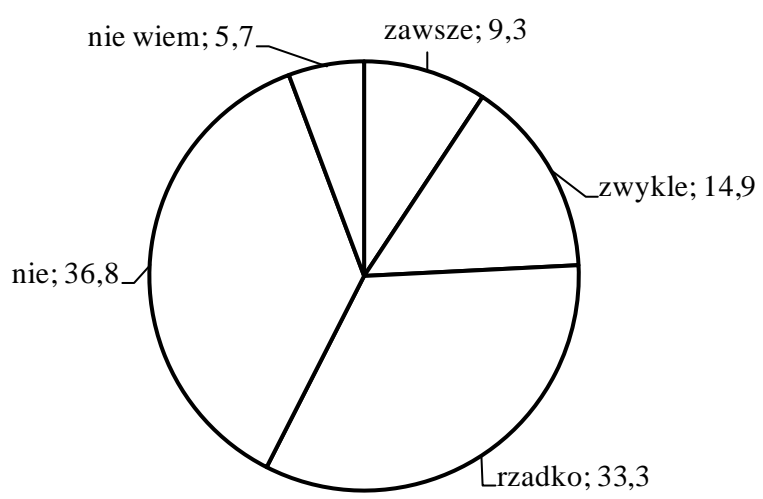

Rys. 12. Jeśli w domu jest pralka automatyczna, czy używana jest wtedy, gdy bęben jest niewypetniony?, \%

Źródło: Opracowanie własne

W kolejnym pytaniu zapytano, czy respondenci zwracają uwagę na oszczędne wykorzystanie wody (Rys. 13). Chodziło przede wszystkim o mycie zębów bez odkręconego kranu czy branie prysznica zamiast kąpieli. 55,7\% respondentów odpowiedziało, że zawsze, a 26,1\% czasami. 


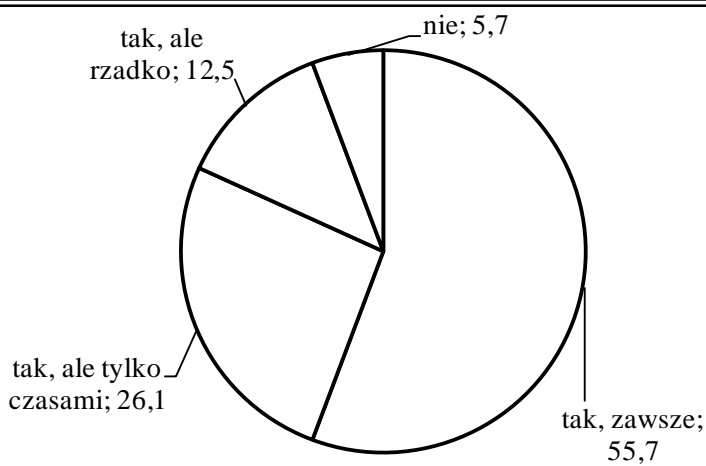

Rys. 13. Czy Pan/Pani zwraca uwagę na oszczędne wykorzystanie wody?, \%

Źródto: Opracowanie własne

Następnie respondenci mieli powiedzieć, jak zazwyczaj myją naczynia (Rys. 14). 52,3\% robi to pod bieżącą wodę, czyli w sposób, który wymaga największego zużycia wody. $35,2 \%$ robi to w zmywarce. Wiele gospodarstw domowych płaci za metr sześcienny zużycia wody, dlatego ludzie starają się oszczędzać te media. Choć w przypadku mycia naczyń pod bieżącą wodą nie jest to tak widoczne. Być może jest to przekonanie, że w ten sposób myje się najdokładniej.

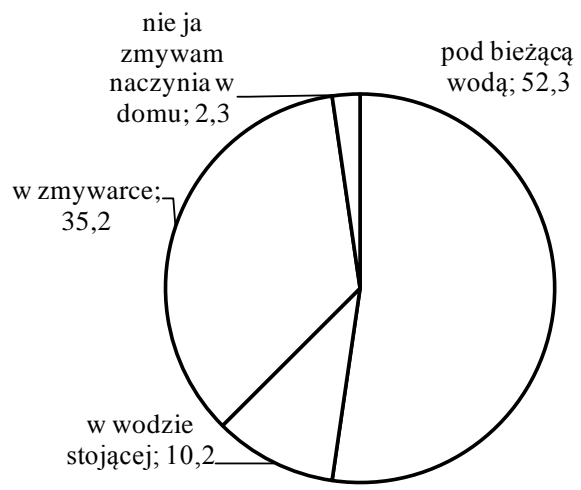

Rys. 14. Jak zazwyczaj Pan/Pani myje naczynia?, \%

Źródto: Opracowanie własne

Respondenci mieli także wskazać, co robią z przeterminowanymi lekarstwami (Rys. 15). 63,2\% z nich powiedziało, że wyrzuca do śmieci, co jest wielce niepokojące. $12,6 \%$ oddaje do odpowiednich punktów odbioru, a 10,3\% do aptek. W przypadku odpowiedzi inne nie podano sposobu. Leki zawierają substancje wpływające negatywnie na środowisko naturalne, a nawet zdrowie i życie ludzi. Substancje te wymagają oddzielnej, kontrolowanej zbiórki i właściwego 
unieszkodliwienia. Być może ludzie nie są świadomi, jak niebezpieczne są to substancje.

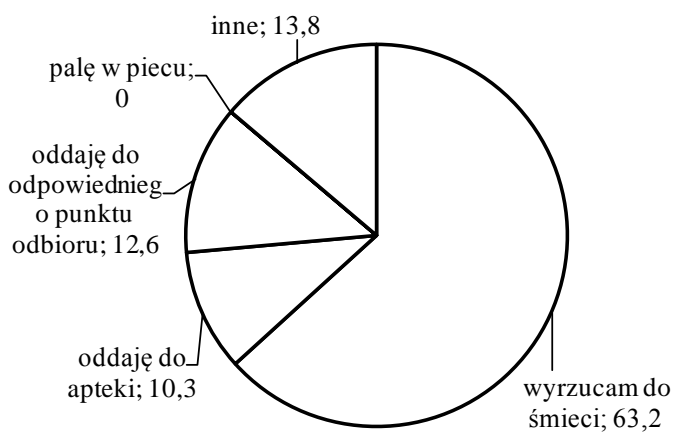

Rys. 15. Co Pan/Pani robi z przeterminowanymi lekarstwami?, \%

Źródto: Opracowanie własne

Ostatnie pytanie dotyczy wykorzystania papierowych ręczników i serwetek (Rys. 16). 46,6\% robi to zawsze, a 27,3\% często. Należy podkreślić, że produkcja takich wyrobów wiąże się $\mathrm{z}$ dużym wykorzystaniem papieru, a tym samym drzew. Bez problemów, zamiast papierowych wersji, można korzystać $\mathrm{z}$ wersji materiałowych, które są bardziej przyjazne środowisku.

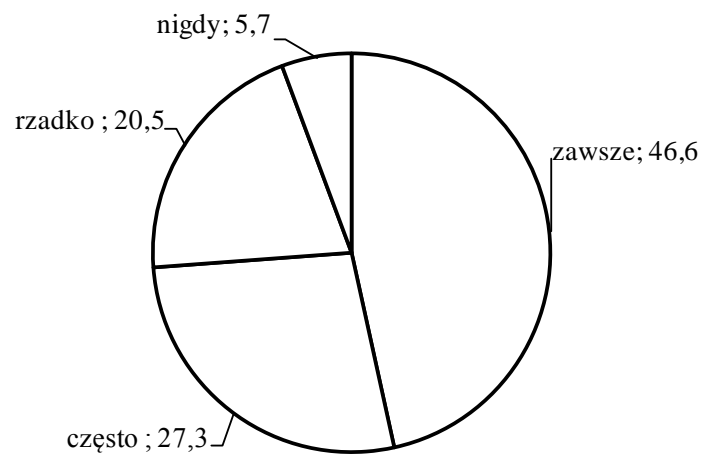

Rys. 16. Czy w Pan/Pani domu używa się papierowych ręczników i serwetek?, \%

Źródto: Opracowanie własne

\section{Posumowanie}

Należy pamiętać, że mamy tylko jedno środowisko naturalne, o które musimy dbać, ponieważ drugiego mieć nie będziemy. Niestety wpływ człowieka na to środowisko, degradacja tego środowiska jest ogromna, a wiele zmian nieodwracalnych. 
W wielu krajach można zaobserwować zjawisko nazywane niedobór, a wpływ na nie mają rozwój technologii, przyrost naturalny (ludność) oraz rosnące potrzeby ludzi. Niedobór widoczny jest na przykład w krajach afrykańskich, gdzie brakuje wody czy jedzenia. Mieszkańcy krajów europejskich nie zdaja sobie sprawy, co mają i jak wiele marnują wyrzucając żywność czy zużywając za dużo wody. Dlatego konieczna jest zmiana podejścia i zrozumienie potrzeb innych oraz potrzeby dbania o środowisko naturalne. Dotyczy to zarówno zwykłych mieszkańców, jak i przedsiębiorstwa.

Przedsiębiorstwa, aby zmniejszyć swój wpływ na środowisko, starają się wdrożyć różnorodne systemy środowiskowe, szukają rozwiązań proekologicznych, prowadzą akcje proekologiczne wśród swoich klientów i dostawców. Ważne jest także uwzględnianie elementów środowiskowych w całym cyklu życia produktu.

Są jeszcze zwykli ludzie oraz ich rodziny, bo przecież tak niewiele potrzeba, by dbać o środowisko naturalne. Każdy może włączyć się w ten proces. Nie potrzeba dużych akcji, dużych kroków. Mogą to być niewielkie zmiany, które wprowadzimy w naszym domu rodzinnym. Można do nich zaliczyć segregację śmieci, niepalenie śmieci $\mathrm{w}$ piecach przydomowych, przemyślane zakupy, oszczędne wykorzystanie energii elektrycznej czy wody, kupowanie naczyń, obrusów, serwetek wielokrotnego użycia.

Wielu powie, że ciężko jest zmienić własne przyzwyczajenia domowe, jeśli do tej pory żyliśmy bez myślenia o skutkach naszego postępowania, zwłaszcza jeśli chodzi o środowisko naturalne. Jednak nie jest to niemożliwe. Wystarczy drobina silnej woli i zrozumienia potrzeby takiego postępowania. Nie tylko pomożemy naturze, ale także będziemy mieć satysfakcję czynienia dobra.

$\mathrm{W}$ artykule przedstawiono wyniki badań ankietowych dotyczących prowadzenia gospodarstw domowych w sposób ekologiczny. Badanie miało charakter ankiety w wersji elektronicznej, która była skierowana do mieszkańców Jury Krakowsko- Częstochowskiej. Dzięki ankiecie można zaobserwować, czy mieszkańcy badanego terenu widzą potrzebę dbania o środowisko i czy uwzględniają ją w życiu codziennym, odpowiednio prowadząc swój dom.

Duża część respondentów deklaruje, że stara się prowadzić dom w sposób ekologiczny, choć przeważająca część robi to tylko w wybranych aspektach. Znaczna większość respondentów deklaruje segregację śmieci, choć niektórzy segregują tylko wybrane typy odpadów. W większości przypadków odpady te trafiają do osiedlowym bądź własnych kontenerów, które opróżniane są przez przedsiębiorstwa komunalne.

Wiele osób zwraca uwagę na to, czy kupuje sprzęt energooszczędny oraz żarówki energooszczędne. Respondenci deklarowali także, że zawsze wyłączają światło, kiedy opuszczają dane pomieszczenie oraz wyłączają $\mathrm{z}$ prądu niewykorzystywane urządzenia elektryczne. Respondenci deklarują, że posiadają 
wiele elektrycznych urządzeń kuchennych, ale niestety także, że ich pralka jest włączana, mimo że nie jest pełna.

Wiele osób stara się także oszczędzać wodę, ale mimo to ponad 50\% respondentów deklaruje mycie naczyń pod bieżąca wodą. Duża część respondentów pozbywa się zużytych lekarstw, wyrzucając je ze śmieciami. Wiele osób używa papierowych ręczników czy serwetek.

Jak wynika z przeprowadzonych badań, respondenci zdają sobie sprawę z tego, że środowisko naturalne jest ważne. Deklarują, że starają się prowadzić dom w sposób ekologiczny, jednak nie zawsze się im to udaje. Być może odpowiednio prowadzona edukacja ekologiczna, różnego rodzaju akcje społeczne dotyczące tego zagadnienia mogłyby wpłynąć na te zachowania, które ekologicznymi nie są. Niestety najtrudniej jest zmienić swoje przyzwyczajenia.

\section{Bibliografia}

[1] Zhuravskaya M., Lempert A., Smorodintseva E. Mathematical Tools for Decision Making Support in Logistic Systems of Different Levels. "Innotrans" Journal, 2012, No 5(6), s. 20-23.

[2] Czajkowska A. Use of OEE coefficient for identification of bottlenecks for pressure die casting processes. METAL 2015. Conference METAL 2015: 24th International Conference on Metallurgy and Materials, TANGER, Ostrava, Czech Rep., 2015, s. 1884-1889.

[3] Cico P., Kotus M., Vysocanska M., Sloboda A. Renovation of sugar beet harvest share - lifespan extension. Listy Cukrovarnicke A Reparske, 2012, vol.128, iss.9-10, s. 280283.

[4] Skurkova K.L., Fejesand, C., Bajor P. The Benefits of Hands-on Learning in Small and Medium Enterprises - an Interactive Way to Enhance Human Capital Potential. Proceedings Of The 6th European Conference On Intellectual Capital (ECIC 2014). Book Series: Proceedings of the European Conference on Intellectual Capital, Slovakia, 2014, s. 226-232.

[5] Almed H.A.A., Amir K.N.B.K., Zulkifli W.A.Z.A.B., Bin Ramli M.N., Salleh M.F.B., Bin Sakidin H. Design and Development of Green Eco-House. UTP-UMP Symposium On Energy Systems 2015 (SES 2015). Book Series: MATEC Web of Conferences, Malaysia, 2016, vol. 28, art. nr 02006.

[6] Furukawa R., Takahashi H.,Sato Y., Sasaki H., Isu N., Ohtsuka M., Tohji K. Small and Shaping the Future Energy Eco-house System. 2ND International Symposium On Aqua Science, Water Resource And Low Carbon Energy. Book Series: AIP Conference Proceedings, China, 2010, vol. 1251.

[7] Ingaldi M., Ociepa-Kubicka A., Seroka-Stolka O. Proekologiczne zarzadzanie w przedsiębiorstwie - wspótczesne problemy i uwarunkowania. Wydawnictwo Wydziału Zarządzania Politechniki Częstochowskiej, Częstochowa 2016.

[8] Pustějovská P., Brožová S., Jursová S. Environmental benefits of coke consumption decrease. Metal 2010: 19th International Metallurgical And Materials Conference, Ostrava, Tanger, Czech Rep., Ltd., 2010, s. 79-83. 
[9] Kardas E. The analysis of the environmental management system in one of municipal plants in Poland. Ecology, Economics, Education And Legislation Conference Proceedings, SGEM 2016, VOL III, Book Series: International Multidisciplinary Scientific GeoConference-SGEM, Bulgaria, 2016, s. 619-626.

\title{
CHARACTERISTICS OF THE HOUSEHOLDS FROM THE ECOLOGICAL POINT OF VIEW
}

\begin{abstract}
More and more often, we can hear about ecological households and how to run a household in an ecological way. It should be remembered that ecology at home does not mean that a person has to invest in modern solutions that cost a lot, and which are supposed to reduce its impact on the natural environment. Each person can develop certain actions, which will not require large amounts of financed expenditure, and which will have a positive impact on the natural environment. The purpose of the paper was to examine the experiences and habits of Polish people in terms of running a household in an ecological way. The study took the form of an online survey. The research was conducted in JuneDecember 2017. Thanks to the research, it was possible to observe the habits of Polish people in the aspect of eco-friendly housekeeping.
\end{abstract}

Key words: eco-house, natural environment, savings, home budget

Data przestania publikacji do Redakcji: 10.05.2018

Data akceptacji publikacji przez Redakcję: 26.07.2018 